\title{
THE ROLE OF THE SOUTHERN AFRICAN DEVELOPMENT COMMUNITY IN THE MANAGEMENT OF ZIMBABWE'S POST-ELECTION CRISIS
}

\author{
Khabele Matlosa \\ Khabele Matlose is Programmes Director - EISA \\ e-mail:khabele@eisa.org.za
}

\begin{abstract}
The political crisis that beset Zimbabwe following its harmonised elections in March 2008 and the controversial presidential run-off poll in June of the same year has triggered heated debate among academics and policy-makers alike. This paper joins this debate. It proposes an analytical framework for our understanding of the crisis and its political ramifications for democratisation in Zimbabwe. In this regard, it problematises the key question, whether or not elections are meaningful to those who have voted if political elites are able to form a government by other means. It unravels the underlying factors behind the post-election crisis, one of these being Zimbabwe's long trajectory of ZANU-PF's political hegemony to the detriment of a viable multipartyism. It investigates $S A D C$ 's intervention through mediation and how far this has taken the country on its democratisation path. While a political settlement has been achieved with the signing of the Global Political Agreement (GPA), the extent to which the key political players adhere to and observe the letter and spirit of the agreement remains moot.
\end{abstract}

\section{INTRODUCTION}

This paper focuses on the political crisis in Zimbabwe after its first-ever harmonised presidential, National Assembly, senate and local council elections on 29 March 2008 and the abortive 2008 presidential run-off. As no presidential candidate garnered the 50 per cent +1 needed to win the presidential race, a runoff poll was held on 27 June 2008. The run-off fuelled intensified political conflict and violence, resulting in the leader of the opposition Movement for Democratic 
Change (MDC), Morgan Tsvangirai, withdrawing from the race and throwing the electoral process into disarray.

Although the candidate for the ruling Zimbabwe African National UnionPatriotic Front (ZANU-PF), the incumbent president, Robert Mugabe, persisted and ran a one-horse race, the credibility of the process and legitimacy of its outcome had already been irretrievably tarnished. The outcome of the election, therefore, became immaterial other than to ensure that externally propelled mediation would play a role in attempts to manage and resolve the post-election impasse. This mediation process was to be facilitated by then-South Africa President Thabo Mbeki, in his capacity as Special Envoy of the Southern African Development Community (SADC), and it is this that forms the fulcrum of the discussion in this paper.

SADC has recently played a key role in mediating post-election conflicts in some of its member states. This is a commendable step by the regional body and is in line with the African Union's decision to replace the age-old culture of noninterference in the internal affairs of member states with that of non-indifference. The process, however, is complex and not without its challenges. The mediator must enjoy the confidence of the contending negotiators and be sufficiently detached. It is clear that the SADC mediator in Zimbabwe, former President Thabo Mbeki, did not enjoy the confidence of all parties. As a sitting president, moreover, there was also the possibility that the internal political dynamics of his own country might influence his role or compromise his mediation efforts.

In the very week that a power-sharing agreement was signed by the main parties in Zimbabwe, namely ZANU-PF, led by Robert Mugabe, and the two formations / factions of the MDC, the MDC-T led by Moran Tsvangirai and the MDC-M led by Arthur Mutambara, Mbeki faced political pressures at home, mainly triggered by faction-fighting within his ruling African National Congress (ANC). This infighting culminated in a decision by the ANC's National Executive Committee on Saturday 20 September 2008 to recall Mbeki from his presidency.

Mbeki's mixed fortunes were tellingly evoked by The Saturday Star: 'In Mbeki's moment of diplomatic triumph in Zimbabwe, the storm clouds gathered ominously at home' (20 September 2008). The toppling of Mbeki plunged the power-sharing agreement into uncertainty at a time when the distribution of ministerial positions had led to a deadlock that would require particular intervention by the mediator. It is worth noting that the Zimbabwe talks had been facilitated by Mbeki (on behalf of SADC) in collaboration with the African Union (AU) and the United Nations (UN). The three inter-governmental organisations, which were also guarantors of the Zimbabwe power-sharing agreement, would now have to make a decision about Mbeki's role. The UN and the AU were expected to take their cue from SADC. 
This paper unravels the inner dynamics and intricacies of the political crisis in Zimbabwe. In the process, it interrogates the role of SADC within the framework of the Strategic Indicative Plan of the Organ on Politics, Defence and Security Cooperation (SIPO) and the SADC Principles and Guidelines Governing Democratic Elections. Both policy frameworks were adopted during the 2004 Annual Summit of Heads of State and Government held in Mauritius. What strategies did SADC adopt to resolve the post-election crisis in Zimbabwe? Have these worked? Are they acceptable, and sustainable? The article attempts to answer these and other related questions confronting Zimbabwe's crisis-ridden governance trajectory since the ill-fated 2008 elections. But before I tackle these questions I introduce a conceptual framework to inform my analysis. It is to this that the next section turns.

\section{A CONCEPTUAL OVERVIEW: \\ DO ELECTIONS SERVE THE PEOPLE OR THE ELITES?}

The discussion in this article unfolds against the backdrop of an emerging debate within both academic and policy communities which seeks to question the value of elections to democracy, peace, and stability, especially in the light of post-election developments in Nigeria (2007), Lesotho (2007), and Kenya (2007).

Nigeria's general election was marred by numerous malpractices, including rigging and mismanagement of the process by the election management body (EMB), leading to a disputed outcome followed by a government-sanctioned electoral reform process. Lesotho's election also had a contested outcome, primarily arising from the misapplication of the electoral model, which had been distorted by the formation of informal election pacts by political parties, which, in turn, distorted the allocation of parliamentary seats. In Kenya, the mismanagement of the elections by the EMB as well as entrenched structural conflicts prompted election-related disputes which triggered a near civil war, only averted by a thirdparty-mediated negotiation process which led to the establishment of a fragile government of national unity.

It should be noted that in all three cases (Nigeria, Lesotho and Kenya), elections triggered political violence, with ghastly consequences for political stability, socio-economic development and the consolidation of democracy. Lesotho's post-election crisis has not, as yet, been resolved. The political crises in Kenya and Zimbabwe were resolved through negotiations that led to some form of power sharing among the political elites. However, in both Kenya and Zimbabwe, the parties to the so-called unity governments still remain worlds apart. This development clearly demonstrates that this power sharing is merely a political marriage of convenience. At the heart of these 'unholy' marriages is 
the desire to satiate the self-serving interests of the political class rather than the aspirations of the people as clearly articulated through the ballot.

The bigger question is whether elections deepen democratic governance or merely act as a political smokescreen for the entrenchment of the interests of political elites. This question has become more relevant with the new phenomenon of negotiated governments (Kenya, Zimbabwe) following contested election results.

In one sense, this trend may be seen as part of the resolution of post-election conflicts and the striving for political stability, peace and national harmony by encouraging concosiational democracy. In another, it may as well pose a threat to the institutionalisation of a culture of regular democratic elections that build a foundation for sustainable democratic governance, as elites determine election outcomes on behalf of the electorate. This is a clear case of elites winning state power by losing elections.

Therefore, in the main, negotiated governments pose the dilemma of whether political stability and peace should be prioritised over and above democracy, or vice-versa. I argue that there is a need in Africa to pursue peace, stability and national unity in tandem with democratic governance, through credible and genuine elections.

An election is a key ingredient of democracy (Elklit 2001, 2007; Elklit \& Reynolds 2005; Sørensen 2008). According to Lindberg (2006, p 1), ‘every modern definition of representative democracy includes participatory and contested elections perceived as the legitimate procedure for translation of rule by the people into workable executive and legislative power'. Thus, while an election has its own intrinsic value (citizens' choice of leadership), it also has an instrumental value, namely, to build, nurture and consolidate democratic governance, peace and political stability. This means that an election for an election's sake is an exercise in futility. An election should not be an end in itself, it must be a means to an end. That end is the movement of society towards a more open and pluralistic politics that allows citizens to participate in the choice of their leaders and the governance of national affairs.

If elections do not contribute effectively to the democratic transformation of society they become mere ceremonial rituals used to camouflage illiberal democracies and authoritarian governance. In a recent seminal work, Sørensen (2008) reminds us that not all elections have led to a transition to democratic governance as some African countries have tended to vacillate between democratic 'transition' and 'standstill', while others have experienced democratic 'reversals'.

Many African countries have experienced a democratic standstill and, according to Sørensen (2008, p 65), 'most of these countries are not on the way 
to more democracy and will probably remain in the gray zone'. It is these grayzone regimes that Fareed Zakaria (cited in Haynes 2001) refers to as illiberal democracies, that is, those regimes that, on the face of it, exhibit democratic tendencies but which, under that veneer of democracy, are deeply authoritarian. Some of the characteristic features of illiberalism include vote buying, legal finetuning, ethnic affirmative action, emergency laws, and restrictions on the right to organise, debate and voice opinions (Haynes 2001).

There is abundant evidence (including the role of the election management bodies in elections and their relationships with the ruling party) to suggest that Zimbabwe has been in the gray zone of democratisation since the mid-1980s. This means that political transition in the country remains unfinished (see Sachikonye 2005, 2006). Thus, the political regime in Zimbabwe can justifiably be classified as an electoral authoritarian regime. Sachikonye (2005, p 10) aptly notes that

When the second democratization wave (see Huntington 1991) swept across the African continent following the end of the Cold War, Zimbabwe did not take advantage of it. Perhaps with the benefit of hindsight, it did not move quickly or steadily on constitutional reform with the expiry of some racially protective clauses of the Lancaster House constitution in 1990. Electoral reform was similarly not addressed although there were obvious weaknesses in the prevailing system. Although elections were held every five years and a nominal multi-party system maintained, democracy was not deepened nor infused into institutions, practices and values.

Given the deep-seated political polarisation and the escalation of inter-party political violence following the elections of 29 March 2008 the indications were that Zimbabwe was not ready for the presidential run-off slated for 27 June 2008 and it could be perilous to undertake such a venture. In such circumstances an election might not prove to be an appropriate means of transferring power.

That is why it is important not to close the option of a negotiated (as opposed to an elected) unity government, premised upon the principles of power-sharing, which could be given a set time frame within which to work on reviewing the constitution and holding a fresh presidential election. In any event, whatever the outcome of the presidential run-off, it is incumbent upon the winner of the election to prioritise nation building, peace, harmony, reconciliation, and socioeconomic recovery and development by making a deliberate effort to establish a government of national unity.

It should be emphasised that negotiated governments should not replace elected governments, they should merely be a stopgap measure intended to 
resolve a specific problem and should not serve the term of an ordinarily elected government. For instance, if an ordinary government would serve a period of five years, the negotiated government could serve a shorter period, perhaps 18 months.

Two very worrying trends are discernible in Africa's recent electoral politics. These relate to protracted post-election violence and to elite pacts that emerge through negotiated settlements that tend (either by default or by design) to undermine the democratic value of elections. Post-election violence has tended to be followed by secret talks involving elites and excluding the voters. Popular choice of government through elections is increasingly being replaced by inter-elite negotiations and popularly elected governments by negotiated governments mediated through third parties sanctioned by regional intergovernmental institutions (eg, the East African Community, with the support of the African Union, in Kenya and SADC, with the support of the African Union, in Zimbabwe).

The political settlement of the post-election conflict in Kenya mediated by Kofi Annan which led to a power-sharing agreement involving the feuding elites who neatly shared the spoils of state power by expanding the executive branch of government and, in the process, shelved the election results, is a case in point. There is no doubt that the negotiation that resolved a deep-seated post-election crisis in Zimbabwe, mediated by Thabo Mbeki as the SADC special envoy, has created another elite pact. A reference group comprising representatives from the UN and the AU supported Mbeki's mediation role.

\section{REGIONAL EFFORTS TO MANAGE THE CRISIS}

Since 2004 SADC has evolved a fairly interventionist policy to deal with political crises in its member states within the framework of the Strategic Indicative Plan of the Organ on Politics, Defence and Security Cooperation (SIPO). SIPO provides a framework for institutionalising democracy and good governance and promoting peace and security in Southern Africa.

Another SADC initiative that aims to advance good governance and political stability is the 2004 SADC Principles and Guidelines Governing Democratic Elections, which is aimed at promoting and ensuring credible and quality elections that are able to deliver legitimate governments. These principles and guidelines, which were adopted in Mauritius during the SADC Summit of Heads of State and Government in 2004, are part of the SIPO.

The first line of the foreword of SIPO reads: 'peace, security and political stability are the linchpins for socio-economic development' (SADC 2004, p 5). The principal objective of SIPO is to 'create a peaceful and stable political and security 
environment through which the region will endeavour to realise its socio-economic objectives' (SADC 2004, p 6). SIPO is divided into four main clusters:

- The Political Sector (democracy and good governance)

- The Defence Sector (military component of security)

- The State Security Sector (policing and intelligence)

- The Public Security Sector (human security)

The SADC Principles and Guidelines have five main components:

- Basic elements for levelling the electoral playing field

- The establishment and deployment of SADC election observer missions (SEOMs)

- Code of Conduct for SEOMs

- Rights and responsibilities of SEOMs

- Responsibilities of member states holding elections

The Principles and Guidelines commit SADC member states to the following best practices in election management, with a view to ensuring high-quality elections and avoiding political instability:

- Full participation of citizens in the political process

- Freedom of association

- Political tolerance

- Elections held at regular intervals, as provided for by the respective national constitutions

- Equal opportunity for all political parties to access the state media

- Equal opportunity to exercise the right to vote and be voted for

- Independence of the judiciary and impartiality of the electoral institutions

- Voter education

- Acceptance and respect by political parties for election results proclaimed to have been free and fair by competent national authorities in accordance with the law of the land

- Challenges to the election results, as provided for in the law of the land.

Since their adoption in 2004 the SADC principles and guidelines have been used by observers in all the member states that have held elections thus far. It is clear that countries in the region have improved their management of elections, especially 
with the introduction of EMBs as the principal interlocutors mediating election contests. However, the principles still face challenges in that SADC member states need to translate them into domestic law by means of deliberate efforts to reform the law. This will ensure that they are not merely a voluntary instrument but that they also become a binding proclamation with legal teeth (Wall, Elis, Ayoub, Dundas, Rukambe \& Staino 2006). The extent to which Zimbabwe's governance architecture has lived up to the SIPO and SADC principles and guidelines remains moot, given its gray-zone character.

The unfinished or stalled transition to democratisation remains one of the most intractable challenges facing Zimbabwe and until the governance crisis is resolved it is unlikely that any of the other socio-economic challenges will be dealt with adequately.

Sachikonye (2006, p 16) decries the poor record of Zimbabwe in this regard:

Apart from the significant step of attaining Independence in 1980, there has been no transition from the prevailing political system and culture to a more open, inclusive and democratic one. It is the absence of such a structural transition that explains both the continued prevalence and defensiveness of authoritarianism, and the prolonged character of the political crisis especially between 2000 and the present. Attempts at engineering a transition have included mediation efforts to encourage a settlement between the ruling Zanu-PF party and the main opposition movement, the MDC, and the revival of the constitutional reform process. The stalemate between the ruling bloc and the opposition movement explains the stalled transition in Zimbabwe.

The political crisis in Zimbabwe has had adverse effects, both internally and externally, on the country's governance and development prospects, as well as on peace, stability, and regional integration in Southern Africa as a whole. It was in recognition of the deleterious impact of the political crisis that SADC felt compelled to intervene directly. The SADC Extraordinary Summit of the Organ on Politics, Defence and Security Cooperation held in Dar Es Salaam, Tanzania, on 29 March 2007 appointed President Thabo Mbeki to facilitate dialogue between the ruling ZANU-PF and the two factions of the opposition MDC.

The primary goal of the Mbeki mediation process was to strive towards a resolution of the governance crisis that would also set the stage for the steady recovery, reconstruction, and renewal of Zimbabwe's ailing economy. There is no gainsaying that at the heart of the country's current dire economic circumstances 
lies a deep-seated governance crisis. It was this crisis that the SADC-mediated negotiation process was intended to address, thereby paving the way for a smooth post-conflict economic recovery and development process.

According to a renowned Zimbabwean political analyst, Brian Rafopoulos ( $M$ \& G March 2008), Mbeki approached the inter-party dialogue process with three objectives in mind:

Firstly, both parties should agree to hold parliamentary elections in 2008. Secondly, they should agree on the steps to be taken to ensure that all concerned accept the outcome of the elections as representing the will of the people of Zimbabwe. Thirdly, that there should be agreement by all political parties and other social forces on the measures that should be implemented and respected in order to facilitate a legitimate election.

The mediation, which started in earnest on 17 June 2007, was only concluded on 12 September 2008. The initial agenda agreed to by the parties to the talks included the following:

i. The Constitution;
a. Process
b. Substantive proposals

ii. The Electoral Laws

iii Security Legislation
a. Public Order and Security Act (POSA)
b. The Access to Information and Protection of Privacy Act (AIPPA)

iv Communication and Media
a. Broadcasting Services Act
b. External radio stations

v. Political Climate
a. Demilitarization of state institutions
b. Hostile rhetoric
c. Militias
d.State aid
e. The role of traditional leaders
f. The lifting of sanctions 
g. The land question

h. Cessation of external interference; and

i. Respect for national events

Although the negotiation process moved at a snail's pace, it yielded modest achievements, including amendments to the Electoral Act, the Zimbabwe Electoral Commission Act, the Public Order and Security Act, the Access to Information and Protection of Privacy Act, and the Broadcasting Services Act. All these reforms led to the amendment of the Zimbabwe Constitution to give effect to the agreed changes.

In the process of affecting the reform measures ZANU-PF called what was, to all intents and purposes, a snap election in March 2008, plunging the negotiations into disarray. The two MDC factions protested the holding of an election before a constitutional review process had been undertaken, while ZANU-PF insisted that the election would go ahead, leading to a deadlock in the negotiations.

The harmonised elections on 29 March 2008 took place in the context of a stalled negotiation process. The president announced the date without prior consultation with the parties involved in the negotiations and well before the negotiations had been concluded, to the chagrin of the opposition parties and the discomfort of Mbeki-it is unclear whether or not he was consulted on the decision. Until that point the negotiations had resulted in a number of constitutional amendments and legal reforms aimed at improving the management of the electoral process and the inclusiveness of electoral politics in Zimbabwe. The major reforms were introduced by Constitutional Amendment 18 of 2007, the main aspects of which were:

- the harmonisation of presidential and parliamentary elections in March 2008;

- provision for two houses of Parliament to sit jointly as an electoral college to choose a new president by a two-thirds majority should the president resign, die, be impeached or become incapacitated in office;

- an increase in the number of members of the lower house from 150 to 210 and of the upper house from 66 to 93;

- the establishment of a human rights commission;

- the establishment of an Independent Electoral Commission

ICG 2007, p 5

The March 2008 election itself was not marred by political violence of the magnitude witnessed during the three previous elections (the 2000 parliamentary 
elections, 2002 presidential elections and 2005 National Assembly and senatorial elections). This, in part, explained the political stability that prevailed prior to and during the poll itself. Despite a number of challenges, including questions about the impartiality of the EMB, the opposition MDC won the elections, as is vividly depicted in Table 1.

Table 1

Results of the National Assembly Elections 29 March 2008

\begin{tabular}{|l|c|c|}
\hline Party & Seats & \% Seats \\
\hline MDC-T & 100 & 47.83 \\
\hline ZANU-PF & 99 & 46.86 \\
\hline MDC-M & 10 & 4.83 \\
\hline Independent & 1 & 0.48 \\
\hline Others & 0 & 0.00 \\
\hline Total & $\mathbf{2 1 0}$ & $\mathbf{1 0 0 . 0 0}$ \\
\hline
\end{tabular}

Source: EISA Website 2008

The process of managing and announcing the results was long and laborious - it was five weeks before the Zimbabwe Electoral Commission (ZEC) announced the official results 'amid mounting regional and international pressure' (ICG 2008, p 5). The MDC-T won 100 seats (47.83\%), ZANU-PF 99 (46.86\%), and the MDC-M $10(4.83 \%)$, while Jonathan Moyo, an independent candidate, won one seat.

Although the MDC had won the National Assembly elections it remained a divided party. It was (and still is), therefore, susceptible to the political machinations of ZANU-PF. Keen observers of Zimbabwe's political scene will know that ZANU-PF has been honing its Machiavellian skills since 1980.

One of its major achievements was the 1987 Unity Accord with the Zimbabwe African People's Union (ZAPU), which led to the virtual demise of the latter. Furthermore, while Morgan Tsvangirai was able to garner a majority of votes in the first round of the presidential poll, he failed to achieve the required $50 \%+1$ to lay a solid claim to Zimbabwe's top political office, as the results in Table 2 illustrate. 
Table 2

Results of the Presidential Elections 29 March 2008

\begin{tabular}{|l|l|c|c|}
\hline Candidate & Party & Total valid votes & $\%$ votes \\
\hline Morgan Tsvangirai & MDC-T & 1195562 & 47.87 \\
\hline Robert Mugabe & ZANU-PF & 1079730 & 43.24 \\
\hline Simba Makoni & Independent & 207470 & 8.31 \\
\hline Langton Towungana & Independent & 14503 & 0.58 \\
\hline Total & & $\mathbf{2 4 9 7 2 6 5}$ & $\mathbf{1 0 0 . 0 0}$ \\
\hline
\end{tabular}

Source: EISA Website 2008

The results reflected in Table 2 related closely to a projection of Zimbabwe's premier elections agency, the Zimbabwe Election Support Network (ZESN). Using a scientifically sound parallel voter tabulation exercise, which, among other things, involved analysing results posted at polling stations, ZESN projected that Tsvangirai would lead the pack of presidential candidates, securing 49.4 per cent of the vote, followed by Mugabe, with 41.8 per cent. Thus, the ZESN predicted that there would be no outright winner of the presidential race, a development that would compel the ZEC to organise a run-off poll.

While the MDC won the National Assembly race and its leader was a mere 2 per cent shy of winning the presidential race, the senatorial poll produced an initial draw between the ruling and opposition parties, as Table 3 shows. The Senate had been re-established in 2005 and an election held in the same year was won by ZANU-PF (see Chiroro 2005). The size of the Senate was expanded from 66 to 93 by means of Constitutional Amendment 18. Article 34 of the Constitution provides that the Senate comprises 93 members.

As will become clear below, ZANU-PF used the political advantage acquired after the 2008 SADC Summit to appoint further senators unilaterally and, in the process, effectively changed the political complexion and balance of power in the upper house. Ordinarily the Senate would have been fully constituted after the new inclusive government was in place, a process that would have involved political horse-trading between and among the negotiating parties. However, it ended up being a solely ZANU-PF body, with no input from the MDC formations. 
Table 3

Composition of the Senate

\begin{tabular}{|c|l|}
\hline $\begin{array}{c}\text { Number of appointees or } \\
\text { elected members }\end{array}$ & \multicolumn{1}{c|}{ Senatorial designation } \\
\hline 60 & $\begin{array}{l}\text { Elected from single member plurality constituencies (6 } \\
\text { from each of the } 10 \text { provinces). Special constituencies were } \\
\text { delimited. }\end{array}$ \\
\hline 16 & $\begin{array}{l}\text { Chiefs elected to the Senate by their peers, on the basis of } \\
2 \text { from each of the } 8 \text { non-metropolitan provinces. The } 8 \\
\text { Provincial Assemblies of Chiefs met on 31 March } 2008 \text { for } \\
\text { the purpose of these elections. }\end{array}$ \\
\hline 10 & $\begin{array}{l}\text { The governor from each of the } 10 \text { provinces, constituting } e x \\
\text { officio members of Senate. Governors are appointed by the } \\
\text { president of Zimbabwe. }\end{array}$ \\
\hline 2 & $\begin{array}{l}\text { The president and deputy president of the Council of } \\
\text { Chiefs are also ex officio members of the Senate. }\end{array}$ \\
\hline 53 & Members appointed by the president. \\
\hline & Total of 60 elected and 33 appointed \\
\hline
\end{tabular}

Source: Constitution of Zimbabwe Amendment Act (No 18) 2007, s 34; EISA Election Observation Mission Report 2008

Table 4

Results of the Senatorial Elections 29 March 2008

\begin{tabular}{|l|c|c|}
\hline Party & Seats & \% seats \\
\hline ZANU-PF & 30 & 50 \\
\hline MDC-T & 24 & 40 \\
\hline MDC-M & 6 & 10 \\
\hline Total & 60 & 100 \\
\hline
\end{tabular}


The political situation deteriorated sharply after the elections of March 2008, thereby setting the scene for a presidential run-off marked by political violence, displacement of citizens, rapid deterioration in socio-economic conditions and the mass exodus of Zimbabweans to neighbouring countries, notably South Africa and Botswana.

It may not be easy to unearth and accurately determine the main factors behind the spate of political violence that followed the harmonised elections, however, anecdotal evidence points to the possibility that ZANU-PF's defeat was not well received by the party, whose tight control of the repressive apparatus of the state allowed it to mobilise to win back its lost glory.

It should be recalled that Zimbabwe was not accustomed to alternation of power (as is, for instance, Mauritius) and this was the first time ZANU-PF's electoral hegemony had been shattered. Undoubtedly, this came as a shock to the party's political heavyweights, 18 of whom lost their parliamentary seats. Among these were Justice Minister Patrick Chinamasa (one of the party's chief negotiators), Agriculture Minister Joseph Made, Women's League leader Oppah Muchinguri, Energy Minister Mike Nyambuya, Mines Minister Amos Midzi, Public and Interactive Affairs Minister Chen Chimutengwede, Transport Minister Chris Mushowe, Kumirai Kangai, the longest-serving ZANU-PF politburo member, and former chief of the Zimbabwe Defence Forces Vitalis Zvinavashe (see ICG 2008, p 3).

ZANU-PF was thrown into a political quandary by the outcome of the election and, in its efforts to respond, two factions fought for the control of the soul of the party. These were the moderate faction (political doves) and the hardliner faction (political hawks), with Reserve Bank Governor Gideon Gono, who has enormous influence over Mugabe, acting as a bridge between them.

The dominant group would push its agenda influencing Robert Mugabe to act accordingly and effectively determining the post-election survival strategy for both Mugabe and ZANU-PF. The reform-minded group of moderates was led primarily by Joyce Mujuru and Joseph Msika (both vice-presidents), who 'called privately for Mugabe to step down following a negotiated settlement' (ICG 2008, p 3).

A status-quo-minded group of hardliners (political hawks), led by Rural Housing Minister Emmerson Mnangagwa, with enormous support from the securocrats, including Defence Force Commander Constantine Chiwenga, Air Force Marshall Perence Shiri, and Police Commissioner Augustine Chihuri, pushed for a political-cum-militaristic approach. This approach was meant to reverse the significance of the outcome of the National Assembly elections and re-engineer the ZANU-PF hegemony by fair or foul means.

Gono and the Mujuru faction of ZANU-PF preferred a negotiated settlement of the political crisis which would obviate a run-off poll. Gono made an unsuccessful 
attempt to caution the government against organising a run-off, arguing that a negotiated settlement should take place first and raising the following arguments, among others:

- The huge cost of the election (US\$60-million).

- The logistical difficulties of organising a run-off within 21 days.

- The strong possibility that losing ZANU-PF candidates would switch allegiance to the opposition, making them unreliable during the campaign.

- The possible serious rifts the run-off would inflict on Zimbabwe's already polarised society.

- The possibility of 'imperialist forces' smuggling help to the opposition to secure its victory

ICG 2008, p 4

Despite these reservations Mugabe opted for the run-off, a clear signal that the hardline faction (led by Mnangagwa) had won the struggle for the soul of the party. Mnangagwa is perceived as the successor to Robert Mugabe and a possible candidate for one of the vice-presidential positions as long as Mugabe remains at the helm of the state.

The anti-MDC sentiment of the security chiefs is no secret - they have not shied away from making their total disdain for Tsvangirai known - and it is their faction that dominated ZANU-PF and influenced all the processes before, during, and after the disastrous run-off poll. Mngangagwa played a key role as manager of Mugabe's political campaign and the security chiefs played a critical role in orchestrating the state-sponsored political violence. The existence of such statesponsored violence has been confirmed by various reports, although it has also been acknowledged that the MDC, too, was responsible for some of the political violence. The joint responsibility of the two parties for perpetrating violence ahead of the run-off is acknowledged in the Memorandum of Understanding (MoU) that set the stage for the power-sharing deal that was eventually struck.

Political violence increased as preparations were made for a controversial presidential run-off that Tsvangirai boycotted in protest, perceiving the violence as state orchestrated. Consequently, the run-off, which took place on 29 June 2008, became a farcical one-horse race in which Mugabe ran alone and was, predictably, declared the winner. Immediately after a swift swearing-in ceremony Mugabe left for Egypt to attend the AU Summit as head of state.

It is worth noting that various influential voices, including the United Nations, the AU, and SADC, had cautioned against holding the run-off election, especially after Tsvangirai pulled out of the race. Even Mbeki tried to dissuade 
the Zimbabwe government from going ahead. ZANU-PF perceived the poll as strategically significant for its survival and that of its leader in two ways. First, the run-off was meant as a political ploy to make up for the party's loss of the National Assembly election to the opposition. The loss had shifted the political balance of forces decisively in favour of the MDC, a shift bolstered by Tsvangirai's defeat of Mugabe in the presidential poll, even though he had not won the $50 \%+1$ required for him to lay claim to the presidency.

The one-man race in June was a tactic clearly intended to turn the tables, claim the moral high ground for ZANU-PF, and wrong-foot the MDC. Having re-positioned ZANU-PF strategically, the outcome of the shambolic run-off would embolden the party ahead of the tough negotiations aimed at putting in place a power-sharing mechanism in the form of an inclusive multiparty government. The election outcome gave ZANU-PF the upper hand as it negotiated as a sitting government, with the MDC negotiating from a position of weakness, as a divided opposition.

Negotiations continued after the run-off poll and, on 21 July 2008, the negotiators signed a Memorandum of Understanding in Harare. The MoU formalised the power-sharing talks that committed the parties to 'a dialogue with each other with a view to creating a genuine, viable, permanent and sustainable solution to the Zimbabwean situation and, in particular, to implement this Memorandum of Understanding' (MoU, 2008, p 2). The MoU outlined the agenda of the talks as follows:

Objectives and Priorities of a new Government

• Economic

- Restoration of economic stability and growth;

- The termination of sanctions

- Tackling the land question

a Political

- New Constitution

- Promotion of equality, national healing and cohesion, and unity

- External interference

- Free political activity

- Rule of law

- State organs and institutions

- Legislative agenda priorities

On the basis of this MoU the parties entered into a negotiation process that was originally planned to last for two weeks. However, because of heated controversy 
over some contentious issues, particularly the power-sharing arrangement, the agreement on an inclusive government was finally signed only on 15 September 2008 in Harare in a ceremony attended by heads of state and government of the 14 SADC member states.

\section{THE OUTCOME OF THE POLITICAL SETTLEMENT}

The SADC special envoy facilitating the negotiations had anticipated that a settlement would be clinched within two weeks after the signing of the MoU. However, this was not to be. The negotiations dragged on, punctuated by the suspension of the talks from time to time, as the negotiators failed to agree on some key issues.

President Mbeki thought that even if the negotiators did not meet the original two-week deadline a deal would be reached before the $28^{\text {th }}$ Summit of the SADC Heads of State and Government scheduled for Johannesburg on 15-17 August 2008. However, by this time no deal had been clinched, to the chagrin of the facilitator and the disappointment of civil society organisations, which lobbied the SADC Summit to take a more robust and firmer stance on two political crises - one in Swaziland, the other in Zimbabwe.

With regard to Swaziland, a civil society forum organised by the SADC Council of Non-Governmental Organisations (SADC-CNGO) noted that a comprehensive and all-inclusive constitutional process would have to facilitate:

- free operation and full participation of political parties in the governance of Swaziland, and

- the holding of democratic elections where political parties are free to contest for election in the country.

The statement further observed that

the common values of SADC as expressed in the spirit and letter of the SADC Treaty and its Protocols as well as the legitimate expectations of SADC citizens that democratic principles are fulfilled in the SADC region do not allow undemocratic States to be appointed to head critical organs of SADC. Accordingly, we urge SADC not to appoint Swaziland to head the SADC Organ on Politics, Defence and Security before the constitutional and electoral challenges facing this country are solved and the SADC Principles and Guidelines on Democratic Elections are respected by Swaziland. 
The SADC-CNGO expressed grave concern about the crisis in Zimbabwe and urged the heads of state and government to ensure:

- that Civil Society be formally included as participants in the present negotiations so that whatever agreement is reached through the negotiations reflects the true will of the people;

- the immediate lifting of the ban on the activities of all NGOs operating in Zimbabwe, including the social welfare and humanitarian organizations that hitherto delivered critical services to poor and vulnerable communities in rural and peri-urban areas;

- the opening up of democratic space to ensure the unrestrained operation of civil society groups, trade unions and all political parties;

- the instant cessation of politically motivated violence, intimidation and acts of harassment against ordinary Zimbabweans, NGO Activists, and Human Rights Defenders;

- the establishment of just, democratic and accountable governance particularly through de-politicization, demilitarization, review and reform of public institutions such as the civil service, state intelligence services, the police force, the army, judiciary, traditional leadership and the legislature;

- restoration of the rule of just law, through a comprehensive, peopledriven and all-inclusive constitutional review process whose product must be endorsed by the Zimbabwean citizenry;

- a clear programme of economic reconstruction based on consensually agreed national development strategies. Such a reconstruction programme must take due cognisance of the need to achieve poverty eradication as well as sustainable and equitable economic growth. In the immediate term, such a programme of economic reconstruction must provide social safety nets for the most vulnerable sections of the Zimbabwean population as well as ensuring the effective functioning of basic social services such as sanitation, health, education, food security and energy

SADC-CNGO 2008

Prior to the 2008 SADC Summit civil society organisations had played various roles in influencing states to find an amicable and acceptable resolution to the Zimbabwe crisis. By far the most remarkable civil society agitation for the speedy resolution of the crisis was the concerted lobby by the trade union movement to block a Chinese ship, An Yue Jiang, from docking in the harbours of any SADC 
member state to offload weapons that were destined for Zimbabwe just weeks before the presidential run-off poll.

The ship, carrying 77 tons of arms, including bullets, mortar bombs, grenades and assault rifles, initially docked in Durban but failed to offload its deadly cargo when the Transport and Allied Workers Union of South Africa, allied to the Congress of South African Trade Union (COSATU), refused to unload the arms. This prompted a concerted lobby by COSATU that saw other SADC countries, notably Mozambique, Namibia, and Angola, taking a similar stand. This civil society pressure further prompted the then-chairperson of SADC, Zambia's former head of state, Levy Mwanawasa, to call, during the SADC International Conference on Poverty and Development held in Mauritius, for all SADC countries to refuse to allow the ship to dock and unload the weapons.

For their part, the SADC heads of state and government were clearly divided on the Zimbabwe crisis, with some adopting a far more critical position than others, arguing that SADC had failed to arrest the situation and to normalise the political and socio-economic situation in the country. Among those who were most critical were Mwanawasa; the new head of state of Botswana, Seretse Ian Khama; and Tanzania's president, Jakaya Kikwete, who was, at the time, chair of the African Union.

Mwanawasa was, however, seriously ill at the time of the summit and could not attend. Zambia was represented by its Minister of Foreign Affairs, Kabinga Pande. Ian Khama deliberately boycotted the summit because he did not recognise President Robert Mugabe as the legitimate head of state. A press release issued by the Ministry of Foreign Affairs and International Cooperation of the Republic of Botswana ahead of the summit stated that:

Botswana does not accept the results of the June $27^{\text {th }}$ run-off election in Zimbabwe as it violated the core principles of SADC, the African Union and United Nations. The legal process of producing a Government in Zimbabwe has failed leading to the on-going talks aimed at forming a Government in that country. The authorities in Harare under the present circumstances should not be represented at the political level at any SADC Summit as that would be equal to giving them legitimacy.

Government of Botswana 15 August 2008

This statement, together with Khama's boycott of the summit, was the most glaring evidence of the divisions within SADC over the political crisis in Zimbabwe. The communiqué issued by SADC's Organ on Politics, Defence and Security (OPDS), an adjunct or political security unit of SADC, then under the leadership of the 
troika of King Mswati III of Swaziland (chair), President Armando Guebuza of Mozambique (deputy chair) and President Jose dos Santos (out-going chair), was optimistic that the negotiations would 'lead to the signing of a global agreement'.

It encouraged the parties to 'sign any outstanding agreements and conclude the negotiations as a matter of urgency, to restore political stability in Zimbabwe' (SADC 2008). But it was also clear that the OPDS was sceptical about a speedy resolution of Zimbabwe's political impasse through negotiations. This may explain why its communiqué also observed that 'while negotiations are continuing, it may be necessary to convene Parliament to give effect to the will of the people as expressed in the Parliamentary elections held on 29 March 2008' (SADC 2008).

A divided SADC seemed unsure how best to respond to the Zimbabwe crisis, a fact that may explain, in part, why it did not deliberate on the subject but delegated this responsibility to the OPDS, creating the dilemma of two centres of power, which has been a problem (real and / or potential) since the establishment of the OPDS in 1996. It also goes some way to explaining why the Summit's communique did not pronounce on any substantial aspects of the crisis, merely observing that 'with regard to the on-going challenges in Zimbabwe, Summit noted the outcomes of the Extra-Ordinary Summit of the Organ held during the course of the Summit and re-affirmed its commitment to work with the people of Zimbabwe in order to overcome the challenges they are facing' (SADC 2008).

The OPDS, left with the substantive deliberations and search for a regional solution, noted that because of the lack of progress towards a power-sharing deal through the creation of an inclusive government the National Assembly of Zimbabwe might be inaugurated and be involved in the search for a solution. Since this recommendation was made there have been two developments:

- The National Assembly has been formally inaugurated and an MDC Member of Parliament elected as Speaker of the House.

- The remaining members of the Senate have been appointed and a ZANU-PF member of Parliament elected President of the Senate

The inauguration of the National Assembly placed pressure on MDC-T, which ZANU-PF and Arthur Mutambara accused of stalling the negotiation process by not signing the draft agreement. However, more importantly, in inaugurating the Senate ZANU-PF consolidated its grip on the levers of state power, ensuring that Mugabe appointed all governors and other non-elected members of Senate without consulting with the other parties.

These two developments tilted the negotiation process critically in favour of ZANU-PF and away from an opposition whose electoral moral high ground 
had been progressively whittled away. In the process ZANU-PF violated article 9 of the MoU, which provides that

the Parties shall not, during the subsistence of the Dialogue, take any decisions or measures that have a bearing on the agenda of the Dialogue, save by consensus. Such decisions or measures include, but are not limited to convening of Parliament or formation of a new government

MoU 2008, p 4

At about the time the National Assembly was inaugurated and the Senate constituted, ZANU-PF and President Mugabe were also threatening to constitute a new Cabinet without consulting with the MDC.

The political balance of forces had shifted radically in favour of ZANU-PF during and after the 2008 SADC Summit and it was little wonder that even the political settlement agreed upon and signed on 15 September 2008 to all intents and purposes reinforced the dominance of ZANU-PF and relegated the MDC to the position of junior partner in the proposed inclusive government.

The signing of the political deal, however, ultimately averted the crisis and ignited a measure of political optimism. Entitled 'Agreement Between the Zimbabwe African National Union-Patriotic Front (ZANU-PF) and the Two Movement for Democratic Change (MDC) Formations, on Resolving the Challenges Facing Zimbabwe', the deal covered agreements on a wide range of issues. The key elements of the power-sharing agreement were:

- retention of the executive presidency with Robert Mugabe still at the helm of the state;

- a call for the lifting of targeted international sanctions;

- commissioning of a land audit;

- a referendum on the new Constitution, to be held within 18 months of the signing of the agreement;

- the setting up of a mechanism for national healing;

- re-training of the security establishment in human rights and democratic governance;

- establishment of a national youth training programme;

- no by-elections for one year;

- public media to provide fair and balanced reporting;

- government to process journalists' applications to work in Zimbabwe;

- foreign-funded radio stations to be discouraged; 
- Zimbabwean expatriates to be encouraged to return home;

- gender parity to be a major consideration in all spheres of government, especially Cabinet.

For the purposes of this article the most remarkable, if controversial, aspect of the deal related to the power-sharing formula agreed upon, which defined how the elites would redistribute state power among themselves without recourse to electoral outcomes. The agreement endorsed the idea of an inclusive government involving the parties that took part in the negotiations and not those that took part in the elections, hence the glaring exclusion of Simba Makoni and his MavamboKusile-Dawn Movement, despite Makoni's impeccable political and technical credentials. Article XX of the Agreement sets out the framework for the inclusive government, defines its character and powers and its make-up. It consists of:

- a president (Robert Mugabe) who still enjoys executive power and chairs Cabinet and the National Security Council;

- two vice-presidents, both from ZANU-PF (retaining the 1987 Unity Accord, which involved appointing one of the vice-presidents from ZAPU);

- a prime minister (Morgan Tsvangirai), who enjoys some modicum of executive power, is a deputy chair of Cabinet, chairs the Council of Ministers and is a member of the National Security Council;

- two deputy prime ministers, one from MDC-T (Thokozani Khupe) and one from MDC-M (Arthur Mutambara);

- 31 ministers -15 nominated by ZANU-PF, 13 by MDC-T and 3 by MDC-M. Of the 31 three may be appointed from outside Parliament with rights to sit and speak in the House but with no entitlement to vote;

- 15 deputy ministers - eight nominated by ZANU-PF, six by MDC-T and one by MDC-M.

Ministers and deputy ministers may be relieved of their duties only after consultations among the leaders of the political parties participating in the inclusive government.

With the overall structures of the new government agreed, the major challenge became the distribution of political spoils among the belligerent elites in the form of ministerial and other public posts. This process, which was intended to begin immediately after the signing of the Global Political Agreement (GPA), was postponed on a number of occasions.

The distribution of ministerial and other public posts (such as the provincial 
governerships, the governorship of the Reserve Bank, and the attorney-general) would ultimately signal clearly which party enjoys the political hegemony with the power to shape and influence considerably how the new Zimbabwean state will evolve.

As indicated above, ZANU-PF has managed, since the 2008 SADC Summit, to pull the rug out from beneath the MDC's post-election moral high ground and bulldoze the inauguration of the National Assembly and the Senate. For a party that lost the parliamentary poll and faced global criticism for holding a one-person presidential run-off, it has achieved a good deal.

Media reports attribute the delay in constituting a meeting of Mugabe, Tsvangirai and Mutambara to agree on Cabinet appointments to the fact that the ZANU-PF Politburo itself had first to meet and pronounce on the issue. It must be noted that within ZANU-PF itself there was no unanimity on the agreement and that factional politics took centre-stage when decisions had to be made on how best to implement it.

The moderate faction of ZANU-PF felt left out of the deal (especially the two vice-presidents, Joseph Msika [subsequently deceased] and Joyce Mujuru). The hardliners and securocrats were also uneasy, complaining that the deal ceded too much power to the 'Western-backed' MDC. Against this backdrop ZANU-PF could not agree on how to share the ministerial posts with the two MDC formations.

The heated disagreements revolved around the allocation of the ministries of Defence, Home Affairs, Finance, Trade and Industry, Foreign Affairs, Agriculture, and Information, among others. SADC has tried, through Mbeki's 'quiet diplomacy', to nudge the parties to the GPA to ensure genuine power sharing, but, beneath the diplomatic veneer, the political hegemony of ZANU-PF has been reproduced in a different guise. This, in part, explains why the inclusive government has not worked to the satisfaction of all the parties, with the MDC constantly protesting to SADC.

As a result of the lack of progress in implementing the GPA and problems afflicting the inclusive government SADC convened an Extra-Ordinary Summit of Heads of State and Government in Pretoria on 26-27 January 2009. This Summit focused specifically on the political crisis in Zimbabwe and took the following decisions:

(i) The parties shall endeavour to cause parliament to pass the Constitutional Amendment Act 19 by February 5, 2009;

(ii) The prime minister and the deputy prime ministers shall be sworn in by February 11, 2009; 
(iii) The ministers and deputy ministers shall be sworn in on February 13, 2009, which will conclude the process of the formation of the inclusive government;

(iv) The Joint-Monitoring and Implementation Committee (Jomic), provided for in the Global Political Agreement shall be activated immediately. The first meeting of Jomic shall be convened by the Facilitator on January 30, 2009, and shall, among other things, elect the chairpersons;

(v) The allocation of ministerial portfolios endorsed by the SADC Extraordinary Summit held on November 9, 2008, shall be reviewed six (6) months after the inauguration of the inclusive government;

(vi) The appointments of the Reserve Bank Governor and the AttorneyGeneral will be dealt with by the inclusive government after its formation; and

(vii) the negotiators of the parties shall meet immediately to consider the National Security Bill submitted by the MDC-T as well as the formula for the distribution of the Provincial Governors

SADC 2009a, p 2

Some of the above decisions have not yet been implemented, including the contentious issue of the appointment of the reserve bank governor and the attorney-general. This, in part, explains why the MDC mounted a campaign for SADC to take a much more robust position in relation to ZANU-PF's stalling on the implementation of the GPA just ahead of the $29^{\text {th }}$ Ordinary Summit of Heads of State and Government held on 7-8 September 2009 in Kinshasa.

It was anticipated that the 2009 Summit would deal, among other things, with the problems facing the implementation of the GPA. However, the Summit issued a diplomatic statement noting 'progress made in the implementation of the Global Political Agreement' and calling on 'the international community to remove all forms of sanctions against Zimbabwe' (SADC 2009b, p 2).

Interestingly, former President Mbeki, did not attend the Kinshasa Summit to give his progress report, as did SADC's mediators in Lesotho (Sir Ketumile Masire, former president of Botswana) and in Madagascar (Mr Joachim Chissano, former president of Mozambique). 


\section{CONCLUSION}

By way of conclusion, a number of interesting features of the Inclusive Government Agreement will be highlighted. Some of these features are positive, others negative.

Firstly, the deal is important as it has brought about the political stability that may lay the foundations for post-conflict reconstruction and development in Zimbabwe. It is worth emphasising that while the deal seems poised to consolidate peace, security, and political stability, its value in facilitating democratisation remains moot.

Secondly, while the deal is intended to bring about an inclusive government it includes only the parties that participated in the negotiation process, excluding others, for instance, Simba Makoni, whose party contested both the parliamentary and the presidential elections. Its inclusivity does not, moreover, fully represent the country's variegated political spectrum.

Thirdly, the process leading up to the formation of the new government, and the very composition of that government, excluded those who had voted in the elections as well as civil society organisations, whose voices were severely curtailed. This is an important point because it suggests that instead of empowering people post-election negotiated elite pacts tend to disempower them, empowering, instead, the political elites.

The popular votes of the Zimbabwean people have been set aside and the whims and caprices of the political elite have dominated the process. The agenda for the dialogue was secret, the venue remained secret outside the borders of Zimbabwe, and the deal relating to the new government remained secret until the public pomp and ceremony that marked the signing of the GPA.

Fourthly, the agreement contains no clause limiting the lifespan of the inclusive government. Consequently, it is not clear whether it is a transitional authority or a government of national unity like that created in Kenya after that country's 2007 election. During the negotiation process there were two schools of thought about this issue. The MDC-T argued that there was a need for an 18-month transitional authority to work on a new constitution and call a fresh election at the end of its tenure. ZANU-PF preferred a government of national unity with a lifespan of five years. Currently, there is a constitution-making process underway, coordinated by a Parliamentary Select Committee and aimed at developing a new constitution, paving the way for a constitutional referendum to be followed by a fresh general election. If this is the route the inclusive government takes it will qualify as transitional, but if it takes the route of a normal period of tenure it is bound to fail as a problem-solving mechanism. 
Fifthly, the deal establishing the inclusive government fails to address the issue of security sector reform as part of the agenda for governance reform in Zimbabwe. This is a major missing link and a political lacuna, given that Zimbabwe urgently needs to demilitarise its violent politics and depoliticise its security establishment. There is no doubt that Zimbabwean politics has been militarised and the security establishment politicised over time, a trend that has intensified since 2000 .

The International Crisis Group report of 2007 acknowledges this:

Zimbabwe's politics was militarized and military coercion became the currency of politics. From March 2000, the state began Operation Tsuro, in which military means were used for political ends. The security apparatus thus became Mugabe's primary source of power.

ICG 2007, p 6

This explains, in part, why the military chiefs declared 'before the 2002 presidential election that they would not salute a president lacking "liberation credentials", a thinly veiled reference to Tsvangirai, a trade unionist who did not fight in that struggle' (ICG 2007, p 7). Consequently, the Joint Operations Command (JOC) plays a central role in policy-making, often overshadowing the Cabinet on many decisions.

The issue of security sector reform cannot be addressed merely by dividing the security sector ministries and departments between ZANU-PF and the MDC, as is currently the case. Much more needs to be done if the GPA is to transcend mere declaratory platitudes and, in the process, transform Zimbabwe's governance architecture and political culture into one of democracy, peace and sustainable socio-economic development. 


\section{- REFERENCES}

AU. 2002. Zimbabwe: Report of the Fact-Finding Mission, African Commission on Human and Peoples' Rights. Addis Ababa, Ethiopia.

Chiroro, B. 2005. 'Apathy, Fatigue or Boycott: An Analysis of the 2005 Zimbabwe Senate Elections'. EISA Occasional Paper No 38, November.

EISA/ECF. 2003. Principles for Election Management, Monitoring and Observation, Johannesburg. EISA publications (mimeo).

Elklit, J. 2001. 'Electoral institutional change and democratization: election administration quality and the legitimacy of "Third World" elections'. In J Haynes (ed). Democracy and Political Change in the 'Third World'. London: Routledge.

-2007. 'Democracy and Elections in Africa'. In K Matlosa, J Elklit \& B Chiroro (eds). Challenges of Conflict, Democracy and Development in Africa. Johannesburg: EISA.

\& A Reynolds. 2005. 'A framework for the Systematic Study of Election Quality'. Democratisation 12(2).

Government of Botswana. 2008. Press Release, Gaborone, Botswana (mimeo).

Haynes, J. 2001. 'Introduction'. In J Haynes (ed). Democracy and Political Change in the 'Third World'. London: Routledge.

Huntington, S. 1991. The Third Wave: Democratisation in the Late Twentieth Century. Norman: University of Oklahoma Press.

International Crisis Group (ICG). 2007. 'Zimbabwe: A Regional Solution'. Africa Report 132, 18 September.

- 2008. 'Negotiating Zimbabwe's Transition' . Africa Briefing No 51, Pretoria/ Brussels, 21 May.

Lindberg, S. 2006. Democracy and Elections in Africa. Baltimore: The Johns Hopkins University Press.

Raftopoulos, B. 2008. 'How SADC Failed Zimbabwe and the Region'. Mail $\mathcal{E}$ Guardian 20-27 March.

Sachikonye, L. 2005. 'Political Parties and Democratisation Process in Zimbabwe'. EISA Research Report No 16. EISA.

—. 2006. 'Consolidating Democratic Governance in Southern Africa: Zimbabwe Country Report'. EISA Research Report No 30. EISA.

SADC. 2001. Protocol on Politics, Defence and Security Cooperation. Gaborone, Botswana (mimeo).

—.2003. Regional Indicative Strategic Development Plan (RISDP). Gaborone, Botswana (mimeo).

-2004. SADC Principles and Guidelines Governing Democratic Elections. Gaborone, Botswana (mimeo). 
- 2004. Strategic Indicative Plan for the Organ (SIPO). Gaborone, Botswana (mimeo).

- 2008. Final Communiqué of the $28^{\text {th }}$ Summit of the Heads of State and Government. Gaborone, Botswana (mimeo).

- 2008. Final Communiqué of the Extra-Ordinary Summit of the SADC Organ on Politics, Defence and Security Cooperation. Gaborone, Botswana (mimeo).

—2009a. Final Communiqué of the Extra-Ordinary Summit of SADC Heads of State and Government. Gaborone, Botswana (mimeo).

- 2009b. Final Communiqué of the $29^{\text {th }}$ Summit of SADC Heads of State and Government. Gaborone, Botswana (mimeo).

Schedler, A. 2002. 'Elections Without Democracy: The Menu of Manipulation'. Journal of Democracy 13(2), April.

Sørensen, G. 2008. Democracy and Democratisation: Processes and Prospects in a Changing World, Third Edition. Boulder: Westview Press.

The Saturday Star 20 September 2008.

Wall, A, A Elis, A Ayoub, C W Dundas, J Rukambe \& S Staino. 2006. Electoral Management Design: The International IDEA Handbook. Stockholm: IDEA. 